\title{
DEBATES SOBRE LA INDUSTRIA EN ARGENTINA: EMPRESARIOS, INTELECTUALES Y PROFESIONALES DE ROSARIO DURANTE LA SEGUNDA GUERRA MUNDIAL
}

\section{DEBATES ABOUT THE INDUSTRY IN ARGENTINA: ENTREPRENEURS, INTELLECTUALS, AND PROFESSIONALS. ROSARIO DURING THE SECOND WORLD WAR}

\author{
Silvia Simonassi* \\ Universidad Nacional de Rosario, Rosario, Argentina, silviags@express.com.ar
}

Resumen. En este artículo se exploran algunos de los principales debates producidos en la ciudad de Rosario durante la segunda guerra mundial sobre el desarrollo industrial regional, en torno a su naturaleza, carácter, posibilidades y límites. El análisis se centra en la convergencia producida entre industriales, intelectuales y profesionales con base en estos temas y profundiza en dos de ellos: el histórico problema del puerto local ante la coyuntura de la nacionalización y las más nuevas demandas de crédito para la industria.

Palabras clave: empresarios; intelectuales; profesionales; desarrollo industrial; ámbito regional.

Abstract. In this article we explore the main debates that have taken place in Rosario during the Second World War, about the nature, the kind, the future potential and the limits of the regional industrial development. We focus on the convergence of industrials businessmen, intellectuals and professionals. We deepen into two subjects: the historical issue of local port and the more recent demands on industrial credit.

Key words: entrepreneurs; intellectuals; professionals; industrial development; region.

Fecha de recepción: 13 de abril de 2015. Fecha de aceptación: 9 de julio de 2015.

* Investigaciones Socio-Históricas Regionales-Nodo Centro de Estudios Sociales Regionales del Consejo Nacional de Investigaciones Científicas y Técnicas-Universidad Nacional de Rosario, Rosario, Argentina. 


\section{INTRODUCCIÓN}

$\mathrm{D}$ esde hace unos años diversas investigaciones han profundizado en los debates que se suscitaron en torno al desarrollo industrial de Argentina durante la primera mitad del siglo Xx. Estos trabajos presentan distintas perspectivas y enfatizan diferentes aspectos; sin embargo, tienen como referente común a Alejandro Bunge y la Revista de Economía Argentina (Bacolla, 2010; Belini, 2010; González-Bollo, 2012; Llach, 1985; Regalsky y Jáuregui, 2003; Rougier y Odisio, 2014a).

Las ideas sobre la industria contenidas en el denominado Plan Pinedo han sido objeto de interpretaciones diversas (Llach, 1984; Pereyra, 1995; Rougier y Odisio, 2014b). El pensamiento económico de Raúl Prebisch en sus distintas etapas ha demandado también atención (Caravaca, 2011; Gilbert, Rougier y Tenewicki, 2000; Love, 1996; Magariños, 1991; Pollock, Kerner y Love, 2001, entre otros), en tanto su actuación al frente de la Comisión Económica para América Latina y el Caribe -en la segunda mitad del siglo- y las ideas sobre la industrialización en América Latina han sido las más conocidas y exploradas.

Para el caso de los economistas, una floreciente línea de investigaciones ha ahondado en el tema de la producción de conocimiento social y en las intersecciones producidas entre el campo académico, el Estado y el mundo empresarial (Caravaca y Plotkin, 2007; Neiburg y Plotkin, 2004; Pantaleón, 2004). En el caso de los ingenieros, se han explorado las ideas difundidas desde la revista La Ingeniería en torno a la propagación de los principios de la organización científica del trabajo (Lobato, 1998, 2003).

$\mathrm{Al}$ enfocar las indagaciones en el universo de las corporaciones empresarias de la industria, son escasas las investigaciones que han explorado el sustento teórico y empírico de las presentaciones escritas que contienen demandas, reclamos, proyectos o propuestas dirigidas hacia distintas agencias estatales nacionales, provinciales o municipales; o la constitución de institutos y centros de investigaciones adscritos a dichas organizaciones, o las convergencias entre el mundo intelectual y el académico con el empresarial, al menos para la primera mitad del siglo XX (Belini, 2014; Lucchini, 1990). Poca atención se ha prestado además a los debates producidos en las provincias en torno al desarrollo económico y el sector industrial. Es el caso de la provincia de Santa Fe y en particular la ciudad de Rosario -un importante centro comercial, universitario y cultural- que llegaría a convertirse en un núcleo industrial de relevancia (Simonassi, 2012).

En consecuencia, en este artículo se exploran algunos de los debates producidos en la ciudad de Rosario durante los años de la segunda guerra mundial sobre el desarrollo industrial regional y su naturaleza, carácter, posibilidades y límites. Se considera a la Federación Gremial del Comercio 
y la Industria de Rosario -la organización representativa de los intereses industriales regionales- y su publicación, Revista de la Federación Gremial del Comercio y la Industria (en adelante Revista), como un "mirador" a partir del cual explorar esas controversias, que excedían sus límites y que develaban tramas de vínculos trazados entre profesionales, académicos, intelectuales y empresarios locales.

Durante este periodo se habría producido un proceso de convergencia entre industriales, académicos, intelectuales y profesionales de la ciudad, en torno a posturas de corte federalista, que propiciaban la necesidad de otorgar impulso al sector industrial regional. Para el logro de este propósito, habrían confluido en la elaboración de un conjunto de argumentos destinados a resaltar la importancia de la acción del Estado para consolidar el sector industrial, a través de la consideración del aporte y la participación de los actores económicos del interior en la elaboración de las políticas públicas, y de ese modo garantizar un crecimiento económico más equilibrado entre Buenos Aires y el heterogéneo interior argentino.

En el primer apartado del trabajo se exhiben los rasgos de la industria local. En el segundo se exponen las posiciones esgrimidas por los principales líderes industriales de la ciudad sobre la industria, las políticas estatales sobre el tema y la descentralización. En el tercero se analizan las ideas contenidas en las publicaciones de un grupo de profesionales e intelectuales acerca de los desafíos de la posguerra en el campo industrial, así como su vinculación -en el terreno de las ideas y de las prácticas- con el mundo empresarial. En los apartados cuarto y quinto se profundiza el proceso de convergencia, centrando el análisis en dos temas gravitantes en el campo empresarial local: los debates sobre la nacionalización-descentralización del puerto local y las posturas respecto a la necesidad de crédito industrial. Por último, se expone un conjunto de conclusiones.

\section{LAS TRANSFORMACIONES DE ARGENTINA Y ROSARIO DURANTE LA SEGUNDA GUERRA}

El estallido de la segunda guerra mundial representó para los países latinoamericanos un nuevo cambio en el sector externo al quedar aislados de los mercados de Europa y Asia. En Argentina en particular, el inicio de la guerra provocó una caída de las exportaciones tradicionales que generalizó el temor a una nueva depresión. El gobierno nacional presentó en noviembre de 1940, ante la Cámara de Senadores, el Plan de Reactivación Económica o Plan Pinedo, que proponía la compra de los excedentes invendibles de los productos agrarios, estimular la industria de la construcción y fomentar las actividades manufactureras. Postulaba también una reforma 
financiera que concediera al Banco Central mayores instrumentos para el manejo de la política monetaria y facilitara la creación de un mercado de capitales a largo plazo. Con el transcurso de los años, los temores y las previsiones pesimistas quedaron atrás; la actividad industrial fue responsable de que en el quinquenio posterior a 1939 el producto bruto creciera a una tasa de $3.6 \%$ anual, se incrementara la exportación de manufacturas desde $2.9 \%$ del total en 1939 a $19.4 \%$ en 1943 y se diversificaran los mercados. No obstante, a la salida de la guerra el sector industrial mostraba severas limitaciones. Las exportaciones industriales habían caído a 13.6\% del total en 1945 y la escasez de materias primas, insumos y maquinarias obstaculizaba la producción (Gerchunoff y Llach, 2007).

Mientras se acercaba el fin de la contienda, militares, funcionarios, intelectuales y empresarios expresaron sus preocupaciones por diversas y nutridas vías. Elaboraron diagnósticos y propusieron la adopción de políticas con el propósito de evitar la desaparición de numerosas industrias, pero también para hacer frente a sus posibles secuelas como el desempleo, la conflictividad y la protesta obrera que ello traería aparejado. Por eso, a partir del golpe de Estado de mediados de 1943 se crearon la Secretaría de Industria y Comercio y el Banco de Crédito Industrial Argentino, se sancionaron los decretos sobre aprendizaje y trabajo de menores y de promoción industrial, se instituyó el Consejo Nacional de Posguerra y se fundó la Secretaría de Trabajo y Previsión, comandada por el coronel Perón, desde donde se promovió la reformulación de las relaciones entre capitalistas y trabajadores.

En lo regional, a principios de la década, varias provincias aprobaron regímenes particulares de promoción industrial. Tal es el caso de Santa Fe, que en 1942 dispuso -por la Ley 3068/42- eximir de impuestos provinciales a las industrias nuevas que utilizaran materias primas hasta entonces no industrializadas en la provincia y reducir gravámenes a aquellas que aunque no utilizaran materias primas nacionales cubriesen necesidades de abastecimiento del mercado interno. Santa Fe representaba, a la salida de la guerra, la segunda provincia industrial del país, detrás de Capital Federal y provincia de Buenos Aires (Simonassi, 2006).

En 1935, el sureño departamento de Rosario concentraba casi 30\% del total de establecimientos industriales de la provincia, cerca de $54 \%$ del personal ocupado, de $49 \%$ de la fuerza motriz instalada y de $56 \%$ del valor agregado por la industria, notablemente por delante del departamento donde está situada la capital provincial, y del colindante San Lorenzo, que dos décadas más tarde será epicentro de una nueva etapa de industrialización en la región (véase cuadro 1).

En 1946 esos porcentajes eran de casi 33, 53, 48 y 48 puntos, respectivamente, con un crecimiento en cantidad de establecimientos y de personal 


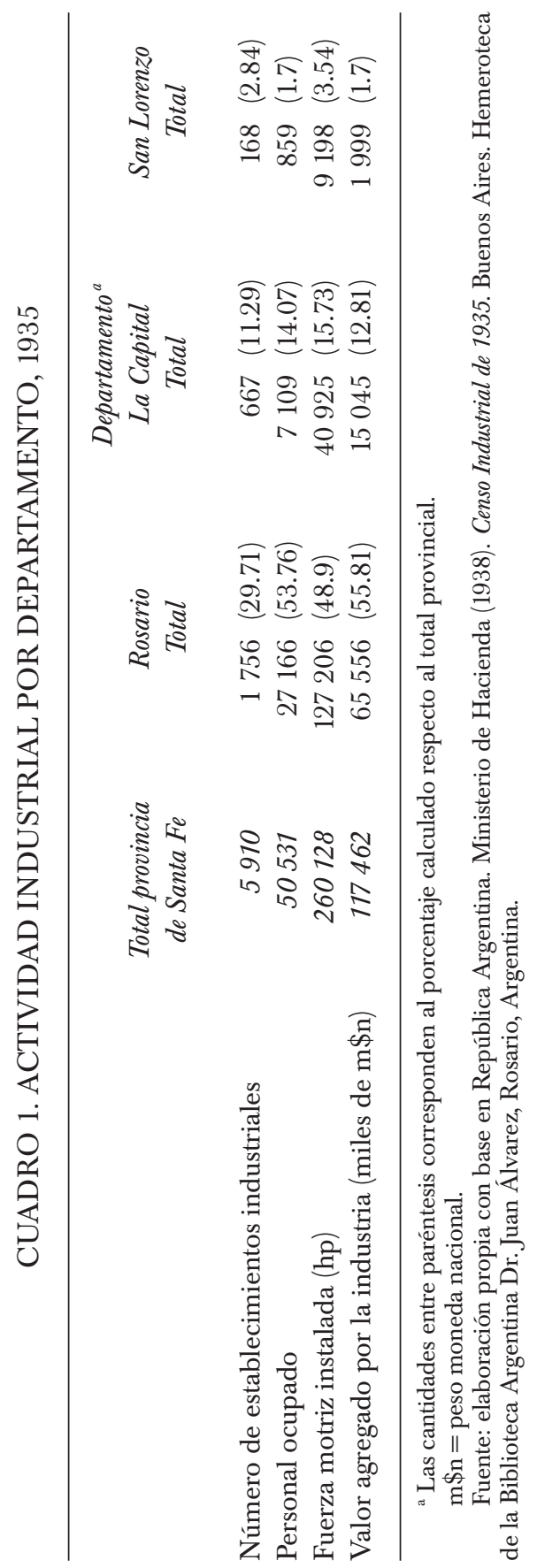


ocupado que casi se había duplicado, llegando a casi 3500 establecimientos y más de 51000 personas empleadas en la industria. Sin embargo, la fuerza motriz instalada había aumentado en proporción menor, lo cual daba cuenta de un crecimiento industrial centralmente basado en el aumento de la cantidad de pequeñas y medianas industrias y en la incorporación de trabajadores, más que en una inversión significativa en tecnología y equipos. Una situación distinta se comenzaba a percibir en el adyacente departamento de San Lorenzo, donde los datos dan cuenta de un proceso inverso (Kofman, Lanciotti y Pérez, 2012; Simonassi, 2012) (véase cuadro 2).

De modo que los años de la guerra constituyeron un periodo de transición para la ciudad de Rosario, entre la dinámica ciudad comercial, intermediaria de la producción agrícola del hinterland circundante, de gran relevancia en el periodo previo, y otra con una estructura más diversificada y orientada hacia las actividades industriales. Este proceso transformó sensiblemente el escenario urbano y social. Durante la segunda mitad de la década de 1930 crecieron los gremios de trabajadores industriales y se consolidaron las organizaciones empresariales que tendieron a representar los intereses de la industria, en particular la Federación Gremial, una organización creada en 1919, en el interior de la cual se agruparon los industriales-importadores (Simonassi, 2012). La ciudad ya contaba con instituciones universitarias consolidadas, como las facultades de Ciencias Matemáticas, Físico, Químicas y Naturales, y la de Ciencias Económicas, Comerciales y Políticas de la Universidad Nacional del Litoral, fundadas en 1919 y 1920, respectivamente.

Durante los años de la segunda guerra, los procesos que sacudieron a la región derivaron en un estrechamiento de vínculos entre el mundo empresarial y el académico, de contornos, formas y magnitudes diversas.

\section{LOS INDUSTRIALES ROSARINOS}

La principal organización de los industriales, la Unión Industrial Argentina, representaba los intereses de los empresarios afincados en Buenos Aires y en particular los más concentrados. Si bien la relación de la rosarina Federación Gremial con esta organización fue muy débil, la más clara adscripción a la Confederación Argentina del Comercio, la Industria y la Producción -representativa de intereses económicos concentrados y de capitales extranjeros-, se agotaba en el transcurso de los años precedentes.

Las organizaciones locales, como la tradicional Bolsa de Comercio de Rosario o el Centro Unión Almaceneros, no contemplaban las demandas específicas del sector industrial. De modo que ante la escasa identificación de los grupos industriales de la ciudad con las organizaciones existentes, la 


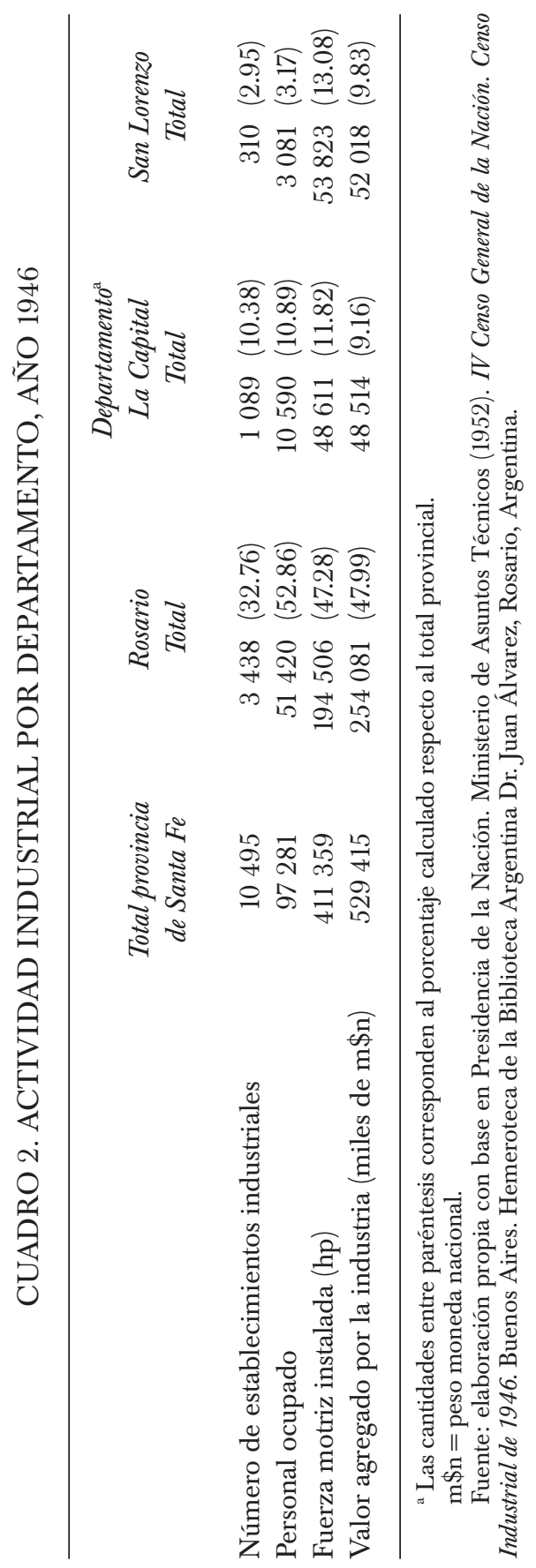


Federación Gremial pasó a ocupar ese espacio de representación corporativa en el ámbito regional.

Sin embargo, este proceso adquirió ritmos y temporalidades específicas. Los años de la segunda guerra mundial representaron para la organización de los industriales rosarinos -y su pugna por la representación- un momento crucial, de definitivo encumbramiento en las comisiones directivas de los grupos burgueses vinculados a las actividades industriales. Ese ascenso estuvo liderado por comerciantes mayoristas e importadores -o sus representantes-, quienes migraron una porción de sus negocios hacia las actividades industriales. En paralelo se desenvolvía otro proceso: el desembarco en las comisiones directivas, de patronos de pequeños talleres, industriales de establecimientos de pequeñas dimensiones, que nutrieron la fundación de cámaras de base, surgidas dentro de la Federación Gremial, como las de madera, mueble, vidrio, metalúrgica, entre otras. Este proceso apenas despuntaba para profundizarse durante los años peronistas.

De modo que el carácter de "bisagra", que revistió al periodo, quedó evidenciado, por un lado, en los principales liderazgos de la Federación Gremial, aún en manos de los industriales-importadores, como en el caso del presidente Ernesto Daumas y del vicepresidente Enrique Vilamajó, y por otro lado, en la progresiva identificación de la organización con la pequeña y mediana industria local y sus intereses y demandas, impulsadas por los nuevos liderazgos.

Daumas ${ }^{1}$ era ya un experimentado líder empresarial cuando fue elegido presidente de la Federación Gremial en 1939 y sus posturas favorables a la industrialización eran conocidas. En 1930, un artículo de su autoría fue publicado en la Revista de Economía Argentina y prologado por el propio Alejandro Bunge, en donde cuestionaba la dependencia de la economía nacional de las exportaciones agropecuarias

cuando las demás naciones se hallan empeñadas en un gigantesco esfuerzo para bastarse a sí mismas, nos exponemos inconscientemente a quedar sin recursos para proveernos de los objetos indispensables a la vida de la población. [...] [El gobierno debía] propender aun a riesgo de disminuir el comercio exterior; a de-

\footnotetext{
${ }^{1}$ Daumas se había desempeñado en la banca y en compañías de seguros locales. En el campo de las actividades industriales, participaba en el directorio de la yerbatera Martín y Cía. Ltda. (Revista, septiembre de 1943, p. 50). Formó parte de Federación Gremial desde 1928 y ejerció un papel relevante durante toda la década de 1930 actuando como presidente de la Sección Industrias, como vicepresidente y como presidente de la organización entre 1939 y 1945 . Fue también directivo de la Bolsa de Comercio de Rosario. Participó además en distintos organismos y comisiones, tanto nacionales como provinciales (Abad de Santillán, 1967; Quién es quién en Argentina, 1955; Rosario biográfico, 1955).
} 
sarrollar los recursos internos del país hasta independizarlo del extranjero en todo cuanto su suelo pueda suministrar (Daumas, 1930, p. 40).

Poco más de una década más tarde, ya como presidente de la Federación Gremial, Daumas (1941, pp. 7-12) sostenía la necesidad de defender y fomentar el sector industrial ante el previsible descenso de las exportaciones para evitar la "disminución del poder adquisitivo interno y externo, paralización comercial, desocupación, baja del standard de vida”; también consideraba que el país poseía condiciones favorables para aspirar "a una total independencia económica [... e] imprimir a su comercio exterior el rumbo y extensión que convengan a sus intereses", de modo que las actividades manufactureras debían "ser intensificadas prudentemente hasta colocarlas en condiciones, cuando así lo exigiera el equilibrio de la balanza de pagos, de proveer la totalidad de los objetos indispensables a la vida y a la defensa de la población".

Para Daumas (1941), el desarrollo industrial estrechaba e incluso eliminaba la dependencia con el extranjero, creaba trabajo y consumo, atraía población, elevaba el nivel de vida social e intelectual: "Hacer en casa cuanta mercancía necesitamos para el propio consumo debe ser nuestro lema[...] Sólo pueden aspirar a su completa independencia política los pueblos que cuentan con recursos propios para vivir y defenderse" (pp. 7-12). Era preciso intensificar el crecimiento industrial en ramas como alimentación, vestido y construcciones para reducir las importaciones y proteger con derechos aduaneros las industrias química, de papel y cartón, vehículos y maquinarias. Para debatir estos temas y ante la urgencia de la coyuntura, Daumas (1940) proponía la constitución de un organismo nacional asesor compuesto por industriales y funcionarios para estudiar y fomentar actividades fabriles "de utilidad pública", mediante el crédito oficial o formando sociedades mixtas (pp. 4-8).

En correspondencia con planteos de ingenieros y militares en el ámbito nacional, Daumas consideraba indispensable encarar la explotación minera para construir la industria pesada. "País sin hierro, [-afirmabaera un] país desarmado" (pp. 4-8), enfatizando así su importancia para la defensa nacional. Las medidas adoptadas por el gobierno, en particular la creación de la Dirección General de Fabricaciones Militares, eran exaltadas por el líder empresario para quien la intervención del Estado se tornaba crucial. Alertaba también sobre un tema que se tornaría central durante la guerra, el problema de la conflictividad obrera, consecuencia natural de la caída de la producción industrial, para lo cual era preciso adecuar la legislación.

$\mathrm{Si}$ estos temas resultaban coincidentes con los que circulaban en la capital nacional, la cuestión de la centralización de las actividades manu- 
factureras fue un tópico particular y recurrente en los debates rosarinos. Para Daumas, en Argentina el centralismo se encontraba exacerbado, lo cual constituía un problema que era a la vez social, económico, político y militar. Para resolverlo, se formularon propuestas y políticas de acción. Se proponía la descentralización de oficinas públicas nacionales, el otorgamiento de mayor independencia a las existentes, la representación de empresarios de las provincias en entes nacionales, una distribución racional de las plantas industriales sobre la base de la proximidad a las fuentes de materias primas y energía y a los mercados de consumo (Daumas, 1940, pp. 4-8). La macrocefalia rioplatense, afirmaba, "no tiene precedente en ninguna otra parte del mundo, y en ninguna época", e ilustraba sus afirmaciones con cifras y porcentajes que fundamentaban su postura. Y finalmente aseveraba: "Tamaña concentración coloca al interior en estado de vasallaje absoluto" (Daumas, 1941, pp. 7-12).

No obstante, Daumas (1940) consideraba que Rosario poseía una sólida base industrial previa (alimentación, papel, fabricación de armas, destilería de petróleo, entre otras) y condiciones propicias (costa accesible a la navegación ultramarina, una significativa población obrera, disponibilidad de agua, tierras de bajo costo, ubicación en la zona de influencia de futuras centrales hidroeléctricas, distancia adecuada a otras grandes aglomeraciones urbanas, red ferroviaria y caminera) que debían ser potenciadas por determinadas políticas estatales (puerto franco y zona industrial, participación de los actores económicos locales en la administración del puerto, exención de impuestos municipales y provinciales) para erigirse como un importante centro manufacturero. Para ello hacía falta una política de descentralización industrial que contribuyese a la creación de fuentes de trabajo y al arraigo de poblaciones de manera equilibrada en el conjunto del territorio nacional (pp. 4-8).

Por su parte, el vicepresidente de la Federación Gremial, Enrique Vilamajó, fue uno de los más activos participantes de los debates sobre la industrialización, sus potencialidades y límites. ${ }^{2}$ Si bien tras la crisis de 1930 sostuvo posturas librecambistas y reactivas a la promoción industrial (véase Vilamajó, 1933, pp. 9-10), este líder empresario se había convertido hacia finales de la

${ }^{2}$ Representaba a Queirolo Hnos. y Cía., una empresa comercial que diversificó sus actividades hacia la industrialización de aceites lubricantes para automotores y máquinas agrícolas, y más tarde a La Continental Cía. de Seguros. Había ingresado en la directiva de Federación Gremial en 1926, fue vicepresidente desde 1927 y presidente entre 1931 y 1935 , para ser designado nuevamente vicepresidente en 1939, cargo que ejerció secundando a Ernesto Daumas hasta 1945. Durante la década siguiente se fue destacando como parte del elenco de funcionarios municipales: como concejal entre 1941 y 1942 y como comisionado municipal entre mayo de 1945 y junio de 1946. Posteriormente fue ministro de Hacienda del gobernador Juan Caesar, alineado con el peronismo. Diccionario biográfico de hombres de negocios (1945) y Entrevista realizada por la autora a Enrique A. Vilamajó, Rosario, febrero de 2015. 
década en un activo promotor de la industrialización y de la descentralización económica y un defensor de la radicación de industrias en la ciudad, para lo cual estimulaba la adopción de políticas activas por parte de los municipios.

En Vilamajó (1938) también aparece con fuerza la necesidad de adoptar políticas para evitar conflictos sociales, pero en su caso los esfuerzos tendían a "conjurar" la fama de Rosario como "la ciudad de las huelgas y de los conflictos obreros" para propiciar radicaciones industriales. ${ }^{3}$ Para "evitar que vuelva a formarse una atmósfera de desprestigio en torno a la ciudad" (Vilamajó, 1938, pp. 19-20), postulaba la intervención estatal en estos temas, así como la responsabilidad empresarial en propiciar políticas como asistencia médica al obrero y seguros de vida que tendiesen a involucrar a los trabajadores "en el éxito de la fábrica, pues de ello depende la seguridad de su hogar" (pp. 19-20). Estas posturas orientadas a exaltar las relaciones armónicas de trabajo, los altos salarios y la creación de dispositivos diversos de bienestar para los trabajadores fueron crecientemente compartidas por empresarios, profesionales y funcionarios y estuvieron asociadas al recrudecimiento de la conflictividad obrera a partir de 1936, potenciado por la recuperación de la economía y el crecimiento de la militancia comunista en los gremios industriales (Simonassi, 2014; Vilamajó, 1938, pp. 19-20).

Vilamajó fue uno de los empresarios que más sistemáticamente cuestionó la desproporción entre la industria de Buenos Aires y Rosario en relación con las posibilidades existentes. De acuerdo con su perspectiva, la falta de una política de fomento industrial y el encarecimiento de las materias primas importadas por el puerto debido a los mayores fletes y gastos eran las razones fundamentales (Vilamajó, 1939, pp. 11-12). No sin cierto pesimismo, el centralismo porteño era señalado como "el mayor obstáculo que tendrá Rosario para su engrandecimiento: la centralización absorbente de Buenos Aires, pero en este punto, el problema deja de ser rosarino para convertirse en argentino, pues afecta a todo el interior de la República” (pp. 11-12). Contrarrestar y revertir esa realidad era, para el dirigente empresarial, tarea del Estado nacional.

La prensa rosarina participó en diversas ocasiones sobre el debate en torno a la industrialización regional y la crítica al centralismo porteño. El diario La Capital reconocía la importancia lograda por la producción industrial en la región, pero advertía enfáticamente sobre la excesiva intervención del Estado y el proteccionismo desmedido. ${ }^{4}$ No obstante, no

${ }^{3}$ El tema de la "fama de Rosario" como ciudad de conflictos se remontaba al menos al periodo 1918-1919, cuando se produjo una importante ola de huelgas; nuevamente, en 1928, importantes conflictos obreros sacudieron la ciudad. Badaloni y Simonassi (2008).

${ }^{4}$ Nuestra evolución industrial (8 de septiembre de 1942, p. 4). La Capital, Rosario; Una política contradictoria (15 de septiembre de 1942, p. 4). La Capital, Rosario; La mutación económica y nuestra evolución industrial (15 de septiembre de 1945, p. 4). La Capital, Rosario. 
dejaba de exaltar el crecimiento registrado por el sector en Rosario. ${ }^{5}$ Por el contrario, La Tribuna, otro de los principales diarios rosarinos, cuestionaba la política oficial para demandar crecientes esfuerzos para impulsar la producción industrial. ${ }^{6}$ Contra el centralismo porteño, sin embargo, se pronunciaban coincidentemente los dos medios locales y convocaban a los rosarinos a luchar para revertirlo. ${ }^{7}$

El gobierno provincial -al frente del cual se ubicó entre 1937 y 1943 la Unión Cívica Radical de Santa Fe, que respondía al radicalismo antipersonalista- promovió el debate en las Cámaras provinciales de una ley de fomento industrial que impulsara el rumbo industrial que la provincia adquiría, potenciando las posibilidades que la segunda guerra mundial había abierto para la satisfacción del consumo interno. No obstante, advertía que la acción estatal debía orientarse a favorecer aquellas industrias que utilizaran materias primas nacionales "para evitar que se creen industrias artificiales antieconómicas, que no podrían sobrevivir en una época normal" ${ }^{8}$ Si bien en esos debates se esgrimieron diferencias respecto a qué industrias proteger y qué porcentajes de exenciones aplicar, todos los partidos con representación finalmente, en 1942, votaron la Ley de Fomento Industrial, con un criterio adverso a la autarquía e inclinado a la promoción de industrias que utilizaran materias primas nacionales o que tendieran a cubrir necesidades del mercado interno.

\section{LOS PROFESIONALES ROSARINOS}

Convergiendo con estas posturas y ante la alarma provocada por la coyuntura del final de la guerra, un grupo de ingenieros y economistas rosarinos editaron una serie de publicaciones, algunas de ellas con el subsidio de empresas y corporaciones empresariales. Entre 1944 y 1945, las publicaciones Argentina económica e industrial (1944) y Argentina en la post

\footnotetext{
${ }^{5}$ Está en pleno desarrollo nuestro proceso manufacturero (2 de septiembre de 1942, p. 11). La Capital, Rosario; Nuestras industrias (3 de septiembre de 1945, p. 4). La Capital, Rosario.

${ }^{6}$ Incremento de las industrias (30 de julio de 1942, p. 7). La Tribuna, Rosario; A favor del fomento industrial (19 de agosto de 1942, p. 7). La Tribuna, Rosario; La sucursal del Banco Industrial fomentará el progreso de esta plaza (2 de septiembre de 1945, p. 10). La Tribuna, Rosario.

${ }^{7}$ La absorción de Buenos Aires y los representantes de la provincia (4 de septiembre de 1942, p. 4). La Capital, Rosario; Hay que rectificar la política arbitraria y centralista que nos asfixia (3 de septiembre de 1942, p. 7). La Tribuna, Rosario.

${ }^{8}$ Provincia de Santa Fe (14 de agosto de 1942). Diario de Sesiones de la Cámara de Diputados. Santa Fe, 1943. Hemeroteca de la Biblioteca Argentina Dr. Juan Álvarez. Rosario, Argentina.
} 
guerra (1946) -a cargo de Pedro J. Cristiá, ${ }^{9}$ Elías Díaz Molano ${ }^{10}$ y Samuel Gorbán, ${ }^{11}$ entre otros- tuvieron como propósito resaltar las limitaciones del proceso de industrialización, que consideraban obedecían a las "improvisaciones, ensayos y extravíos" de los sucesivos gobiernos, al tiempo que aseveraban que era posible torcer el rumbo reestructurando la economía en la posguerra (Cristiá et al., 1946).

Cada capítulo de Argentina en la post guerra, abordaba de manera autónoma los diferentes temas - población, salud pública, producción, energía, industria, comercio exterior, bancos y régimen impositivo- y culminaba con diversas propuestas de acción. En el capítulo correspondiente, Cristiá et al. (1946) reseñaban la historia de la industria hasta 1935 a partir de datos censales, mientras que para analizar la evolución del sector industrial durante la guerra hasta 1942 utilizaban estadísticas industriales.

Allí, Cristiá et al. (1946) resaltaban el "extraordinario empuje alcanzado por nuestra industria en su afán de cubrir nuestras necesidades y al mismo tiempo estructurar una gran industria nacional" (p. 303), así como las limitaciones: el crecimiento de industrias, como las de maquinarias y vehículos, sin el correspondiente aumento de personal ocupado, un constante incremento de las exportaciones de productos industrializados, pero también una notable participación de materias primas importadas en ramas fundamentales como la citada. Esta situación era particularmente remarcada como demostración de la dependencia económica: "la independencia de un país no se alcanza única y exclusivamente a través de su industrialización, sino que ella constituye un proceso de magnitud y complejidad en el que se incluyen numerosos factores entre los cuales, al lado

${ }^{9}$ Pedro Cristiá fue ingeniero civil, graduado en la Universidad Nacional del Litoral. Publicó diversos estudios sobre temas económicos, financieros y técnicos. Se convirtió además en un importante referente empresarial a través de su accionar en la Asociación de Comerciantes e Industriales de la Zona Norte de Rosario, la Federación Económica de la Provincia de Santa Fe, integrante de la Confederación General Económica y líder de esta a fines de la década de 1960. Fue docente en la Escuela Industrial de la Nación y en la Facultad de Ciencias Matemáticas de la Universidad Nacional del Litoral. La Federación Gremial lo definió como un "profesional conocido en nuestro medio por sus trabajos y por su lucha anticentralista". Revista (octubre de 1946, p. 36).

${ }^{10}$ Elías Díaz Molano fue ingeniero químico egresado de la Facultad de Química Industrial y Agrícola de la Universidad Nacional del Litoral, con sede en la ciudad de Santa Fe. Fue director de la Escuela de Electrotécnica y Mecánica y docente de la Escuela Industrial de la Nación y de la Facultad de Ciencias Matemáticas. Más tarde ocupó el cargo de vicedecano de la regional local de la Universidad Tecnológica Nacional (Abad de Santillán, 1967). Entrevista realizada por la autora a Luis Díaz Molano, hijo de Elías Díaz Molano, Rosario, enero de 2015.

${ }^{11}$ Samuel Gorbán fue doctor en Ciencias Económicas egresado de la Facultad de Ciencias Económicas, Comerciales y Políticas de la Universidad Nacional del Litoral. Había sido presidente de la Federación Universitaria del Litoral y delegado al Consejo Superior de dicha universidad. Fue docente de la Facultad de Ciencias Económicas entre 1955 y 1966 y decano de la misma. Gorbán se desempeñó además como síndico de distintas empresas locales (Abad de Santillán, 1967). 
del desarrollo industrial, se encuentra el de la reconquista de los servicios públicos, aumento de la población, creación de fuentes de energía permanente y creación de una conciencia nacional...” (p. 303).

En esta obra colectiva se postulaba la pertinencia de la intervención estatal en diversos aspectos: si bien los autores entendían que el Estado debía fomentar las industrias que utilizaran materias primas nacionales, avanzaban en la propuesta de explotar recursos naturales que permitan:

levantar... la gran industria siderúrgica que el país necesita y nuestra economía reclama [...] Cuando de nuestras fábricas salgan las máquinas industriales que hasta hoy importamos, cuando nosotros mismos fabriquemos los repuestos para ellos, cuando hayamos levantado altos hornos y fabriquemos elementos de precisión, entonces y solamente entonces, habremos alcanzado un grado de industrialización tal, que será uno de los sólidos pilares sobre los que ha de asentarse nuestra total independencia económica y política (1946, pp. 305-306).

Aunque aún no estaban generalizadas en las corporaciones rosarinas, las ideas sobre la necesidad de promover la industria pesada formaban parte de la ideología sobre la industrialización que circulaba en los textos que leían y financiaban los industriales y eran adoptadas por algunos de sus líderes, como es el caso del propio Daumas.

En cada uno de los capítulos de este libro, los autores se ocupaban de analizar los desequilibrios existentes entre Buenos Aires y el interior, y sancionaban: "Buenos Aires nos gobierna política y económicamente como el emperador a sus vasallos" y "Nuestro régimen de federalismo político fracasa, entre otras razones, porque no descansa sobre el federalismo económico" (p. 7). En este aspecto era fundamental la actuación del Estado para promover la eliminación de fletes diferenciales y las desigualdades impositivas, el acercamiento de las reparticiones oficiales, el desarrollo de una red caminera, la canalización de los ríos, la electrificación de los saltos de agua que promuevan la industrialización de la materia prima en las zonas de origen (p. 319). El Estado debía mirar hacia el interior del país, buscando en sus "inexploradas riquezas la fuente inagotable de nuestro progreso incesante. Cuando eso se haga habrá desaparecido el mito de las provincias ricas y provincias pobres" (pp. 323-324). En el tema del comercio exterior, consideraban imperiosa la defensa de los nuevos mercados conquistados durante la guerra, intensificando el comercio con los países latinoamericanos y con la URSS, que tras el restablecimiento de las relaciones diplomáticas aparecía como un mercado inmenso y proveedor de petróleo y maquinarias. Proponían el desarrollo de los mercados del interior del país, la ampliación y diversificación de las exportaciones y la 
planificación de las importaciones con miras a la sustitución de equipos agrícolas e industriales, de transporte y servicios públicos.

De modo que el libro continuaba -en algunos casos en que se había dificultado el acceso a nuevos datos- la línea de Argentina económica e industrial, publicación cuya financiación estuvo a cargo de diversas organizaciones empresariales y profesionales de la ciudad. La nómina de casi 70 organizaciones y empresas denotaba heterogeneidad -grandes y medianas empresas industriales, bancarias, de seguros, de la construcción, nacionales y extranjeras-, lo cual resultaba expresivo del amplio universo de sectores que compartían preocupaciones sobre la proximidad de la posguerra. Los temas abordados en esa primera publicación eran similares: población, salud e instrucción pública, producción, petróleo, energía, industrias, desequilibrio económico, transporte y comunicaciones, comercio exterior, bancos, gasto público e impuesto a los réditos y en todos ellos el problema del centralismo resultaba prioritario.

A su vez, los autores de Argentina económica e industrial y de Argentina en la post guerra publicaron trabajos sobre algunos de los problemas parciales abordados en esas obras de síntesis. Por ejemplo, Pedro J. Cristiá tuvo a su cargo la investigación del contrato entre la Sociedad de Electricidad de Rosario y (hacia mediados de 1944) la por entonces Empresa Mixta de Transporte de Rosario, poco después municipalizada (Cristiá, 1945a). El estudio había sido encargado por la dirección de la empresa antes de la municipalización, para analizar las condiciones del contrato y posibles soluciones a futuro para la provisión de energía para tracción y servicios auxiliares. Cristiá (1945a) se propuso abordar el cometido atendiendo al carácter de "empresa popular y estatal o semi-estatal" antes que como una empresa puramente comercial, es decir, "deberá tenerse en cuenta la vinculación que la E. M. tiene con la Municipalidad, y dada tal circunstancia, contemplar la posibilidad de que esta en colaboración con aquella recupere el servicio eléctrico de toda la ciudad" (p. 9). El carácter del estudio excedía los aspectos puramente técnicos, para desnudar las condiciones abusivas de los contratos suscritos con grandes empresas extranjeras proveedoras de servicios públicos y la conveniencia de su nacionalización, convirtiéndose en un excelente y documentado instrumento de denuncia y de acción pública. ${ }^{12}$

${ }^{12}$ De la investigación resultó que el costo de la energía eléctrica en el servicio tranviario sobrepasaba 20\% de las entradas, no obstante ser la Empresa Mixta un cliente de "calidad" superior al resto -el primero en la ciudad y el segundo dentro y fuera del municipio-, la "Empresa Mixta recibió de la Sociedad de Electricidad de Rosario un tratamiento peor" que el resto. Recomendaba reliquidar las sumas pagadas "sobre la base de que el precio de la energía eléctrica para el servicio tranviario debe ser "justo y razonable" y estudiar de inmediato la posibilidad de instalar una usina propia para el servicio tranviario o en combinación con la municipalidad, también 
Cristiá y Vicente Ottado (1946) escribieron sobre ferrocarriles. Pedro J. Cristiá se destacó además por intervenir en el debate sobre problemas técnicos-sociales, en particular en las controversias acerca del aprendizaje industrial, promoviendo además la apertura en la ciudad de escuelas medias con el objetivo de formar técnicos para la industria (Cristiá, 1944b y 1944c; Simonassi, 2011). En su tesis doctoral, presentada en noviembre de 1950 y publicada poco después, Samuel Gorbán analizó el tema de la integración económica de América Latina y caracterizó a las economías latinoamericanas como "deformadas por la acción combinada del capital monopolista foráneo y las clases dirigentes indiferentes o tolerantes" (Gorbán, 1950, 1951). En 1947 publicó un libro sobre planificación industrial prologado por Cristiá (Gorbán, 1947).

El grupo promotor de Argentina económica e industrial publicó a partir de entonces en la Editorial Rosario, la cual constituyó un espacio de convergencia entre los ámbitos empresariales y académicos. Estuvo conformada por dirigentes empresariales de la Bolsa de Comercio y Federación Gremial, e intelectuales como Cristiá, Cortés Pla, Díaz Molano y Gorbán, junto con Laudelino Ruiz, librero y editor. La empresa tuvo su sede en instalaciones de la Bolsa de Comercio. Allí, y en la empresa de Ruiz, el grupo realizaba periódicamente reuniones improvisadas o planificadas. La editorial publicaba temas científicos y literarios y las investigaciones económicas fueron incluidas en la serie Temas de Economía. ${ }^{13}$

En estas publicaciones los temas del desarrollo industrial eran abordados a partir de información cuantitativa disponible, aunque no siempre actualizada. Utilizaban profusamente información contenida en la prensa periódica y corporativa, así como documentación oficial, en particular memorias de diversas agencias estatales. Como entre sus autores encontramos predominantemente ingenieros y economistas -y también un médico- no resulta llamativo que las ideas fueran tributarias de fuentes diversas, aunque buena parte de sus posturas estaban mediadas por la lectura de integrantes de la Revista de Economía Argentina, como Alejandro Bunge, Francisco García Olano, Emilio Llorenz, el teniente coronel Mariano Abarca, Ernesto Herbin y Adolfo Dorfman, intelectuales que participaron en los debates en la capital nacional. La heterogeneidad de las fuentes

para el alumbrado público. El estudio contenía además un exhaustivo análisis sobre la empresa, a través del cual se demostraba la vinculación o "dependencia" entre la Sociedad de Electricidad de Rosario, la Compañía General de Tranvías Eléctricos de Rosario y la Societe Financiere de Transports et d'Enterprises Industrielles (SOFINA) a través de una indagación de los principales accionistas y los domicilios declarados. Se exponía además la amplitud territorial y la magnitud de los intereses del superholding Sofina en todo el mundo. Cristiá (1945a). Para un análisis del negocio de provisión de energía eléctrica en Rosario, véase Fernández (2009).

${ }^{13}$ La serie se completaba con los títulos de Astesano (1950) y López-Mayer (1946). Entrevista realizada por la autora a Liliana Ruiz, hija de Laudelino Ruiz, Rosario, enero de 2015. 
intelectuales que eran citadas en estos trabajos da cuenta asimismo del pragmatismo que impregnaba sus ideas económicas y sus propuestas de política industrial.

Varios ejes de debate, como el tipo de industrias que caracterizaría el desarrollo industrial, el mercado de destino de la producción fabril y el papel que asumiría el Estado en dicho proceso (Belini, 2010), coincidieron con los transitados en Buenos Aires. No obstante, los intelectuales rosarinos profundizaron en aspectos escasamente abordados, en particular los asociados a las economías del interior y sus problemas. Fue precisamente de esta forma como los empresarios locales, y los industriales en particular, se apoyaron para elaborar y difundir sus demandas.

En ese diagnóstico sobre las limitaciones del desarrollo industrial regional, algunas cuestiones eran particularmente destacadas. A continuación se despliegan dos problemas principales y el modo en que fueron abordados, para hacer inteligible este rasgo distintivo de las ideas económicas de intelectuales, profesionales y empresarios de una región del interior argentino. Se trata de temas que son considerados medulares y que esclarecen, además, el citado proceso de convergencia entre empresarios, profesionales e intelectuales.

\section{NACIONALISMO Y FEDERALISMO EN LOS DEBATES SOBRE EL PUERTO}

Los debates sobre el problema portuario anudaron problemas propios de la guerra, la industrialización y el creciente centralismo de las actividades económicas en Buenos Aires. En rigor, el tema había despertado el interés de los principales actores económicos y políticos desde su propia planificación y puesta en funcionamiento. Desde principios del siglo Xx y hasta octubre de 1942, su explotación había estado a cargo de una empresa extranjera, la Sociedad Anónima Puerto Rosario, y representaba el segundo puerto en importancia a nivel nacional. Se había caracterizado por recoger la producción de Santa Fe, Córdoba y el norte del país y era punto obligado en la navegación de cabotaje del Río Paraguay y Alto Paraná, que interconectaba sitios como Asunción y Buenos Aires y los de la provincia de Entre Ríos y Corrientes (Lázzaro, 1992). Había alcanzado durante la década de 1920 el máximo nivel de actividad como principal centro de exportación de granos del país y uno de los primeros del mundo.

Durante la década de 1930, y a pesar de la crisis, la exportación de productos agrícolas, en particular el maíz, creció, mientras las importaciones, que no habían sido históricamente relevantes en el movimiento portuario local, perdieron aún más preponderancia para decrecer todavía más en la década siguiente. Para 1938 se calculaba que alrededor de 5\% 
del total de las importaciones ingresaba por Rosario. Sin embargo, en los años de la segunda guerra mundial, combustibles y lubricantes, hierro, cemento, madera y asfaltos provenientes de Inglaterra y Estados Unidos entraron en cantidades significativas, destinados a proveer de insumos a la industria local (Fernández y Armida, 2000).

Durante el plazo que duró la concesión, las condiciones arbitrarias impuestas por la empresa generaron múltiples controversias. Durante la guerra, las peticiones de los principales actores económicos de la ciudad circulaban alrededor de diversas cuestiones irresueltas: la necesidad de contar con infraestructura y servicios adecuados, el abaratamiento de tarifas, la canalización del río Paraná y la instalación de zonas francas que promovieran la descentralización del puerto de Buenos Aires (Simonassi, 2012).

Ahora bien, a esos antiguos ejes de debate se añadieron las controversias sobre el futuro del puerto tras el vencimiento de la concesión, en octubre de 1942. Esta situación fue percibida por empresarios de las distintas corporaciones locales, profesionales y funcionarios locales como la posibilidad de revertir problemas largamente irresueltos interviniendo en las transformaciones que se avecinaban. La prensa local cumplió también un papel importante presionando en la misma dirección.

En 1940 fue conformada, por iniciativa de la Facultad de Ciencias Matemáticas y con la presidencia de su decano, el ingeniero Cortés Pla, una comisión de empresarios y académicos para estudiar el problema del puerto. El dictamen fue entregado al ministro de Obras Públicas a principios de 1942 y abordaba diversos aspectos del problema: en lo concerniente a la transferencia, y ante diferencias en la interpretación de los derechos de la empresa concesionaria, resaltaban el derecho del Estado nacional a percibir la suma que correspondiera, sometiendo cualquier diferencia a los tribunales nacionales, sin alterar la fecha del fin de la concesión. Sostenían, además, la necesidad de conformar una comisión integrada por funcionarios y "privados" para estudiar cuestiones técnicas y administrativas de la transferencia y que la futura administración del puerto quedara a cargo de una entidad autárquica con participación estatal y privada. Se pronunciaron también sobre el tema de las tarifas, las obras de ampliación, la canalización, es decir, se pronunciaron a favor de atender los reclamos históricos de mejoramiento de la infraestructura y potenciación de las condiciones existentes, así como de erigir una zona industrial en el puerto y fomentar el comercio de cabotaje. ${ }^{14}$ En similares términos se pronunciaron los líderes empresarios, que presionaban para avanzar en la discusión sobre la futura gestión.

${ }^{14}$ Memoria de la Bolsa de Comercio de Rosario (1940), pp. 41-42, y Memoria de la Bolsa de Comercio de Rosario (1941). Comisión Estudio Problema Puerto Rosario, pp. 37-39. 
Por el contrario, desde el Ministerio de Obras Públicas la principal preocupación, consistía en estudiar las condiciones de la transferencia y los aspectos técnicos, postergando la decisión sobre la administración futura. ${ }^{15}$ Los argumentos desplegados se orientaron a insistir en que tras el vencimiento de la concesión, la gestión y administración debía confiarse a una comisión mixta integrada por empresarios locales. El gobierno provincial apoyaba las gestiones y posiciones de las corporaciones rosarinas (Adhesión a las gestiones, agosto, 1942, p. 21).

Finalmente, el gobierno nacional creó la comisión asesora integrada por empresarios y funcionarios públicos, pero en su interior rápidamente se planteó la tensión entre los partidarios de la administración centralizada y aquellos que abogaban por la descentralización. ${ }^{16} \mathrm{El}$ presidente de la Bolsa de Comercio local, Arturo Atlántico Dianda, ${ }^{17}$ como parte de la comisión, defendía la "unidad de dirección ejercida sobre el terreno de los acontecimientos" (Visitó nuestra ciudad, julio, 1942), al otorgar capacidad de decisión a las personas e instituciones representativas de las actividades económicas regionales. Postulaba que la centralización representaría un retroceso, caracterizado por la tramitación directa con la empresa en el orden local y "una simple cesión al fisco de su principal instrumento de trabajo para que el Estado lo maneje a distancia" (p. 3). ${ }^{18}$ El gobierno procuraba llevar el debate hacia la nacionalización de los puertos y la unificación del sistema portuario argentino, tema que los empresarios rosarinos proponían postergar.

Estas divergencias condujeron a los actores rosarinos de la disputa a incrementar las acciones de presión. Una profusión de publicaciones esgrimía argumentos técnicos, económicos y jurídicos, conformando un movimiento de opinión local. ${ }^{19}$ Es el caso de Francisco E. Lecchini (1942), quien analizaba los factores primordiales a considerar en el debate: tarifas portuarias y ferroviarias, estado de las instalaciones, accesos, formas de prestación del servicio, o Natalio Muratti, Rafael Bielsa y Gregorio Mei-

${ }^{15}$ Memoria de la Bolsa de Comercio de Rosario (12 de agosto de 1941. Nota del ministro de Obras Públicas al presidente de la Bolsa de Comercio de Rosario, Buenos Aires, pp. 28-29).

${ }^{16}$ Memoria de la Bolsa de Comercio de Rosario (1942, pp. 27-28).

${ }^{17}$ Estaba al frente de S. A. Minetti y Cía. Ltda., una importante fábrica de la rama de la alimentación. Presidió la Bolsa de Comercio local entre 1933 y 1946. (Abad de Santillán, 1967 y Quién es quién en Argentina, 1955).

${ }^{18}$ El memorial defendido por Dianda estaba avalado por representantes de la Bolsa de Comercio; la Federación Gremial; la Sociedad Rural de Cerealistas; el Colegio de Abogados; la Sociedad Central de Arquitectos; la Comisión Estudio Problema Puerto Rosario; el Centro de Corredores y Consignatarios de Cereales; la Cámara Gremial de Molineros del Norte; el Centro Marítimo de Rosario; el Centro de Exportadores de Cereales; el Centro de Cabotaje del Litoral y la Asociación de Ingenieros de Rosario y Sociedad Rural.

${ }^{19}$ Memoria de la Bolsa de Comercio de Rosario (1942). 
ra. ${ }^{20}$ La prensa local contribuyó en el mismo sentido (La Tribuna, 24 de julio de 1942, p. 7).

Finalmente se impuso el criterio de nacionalización del puerto de Rosario bajo una administración centralizada, lo cual representó la frustración de los anhelos de los empresarios locales de tomar parte en el control y la gestión de la puerta de entrada y salida de mercancías de la ciudad y la región.

Los industriales rosarinos, a través de sus publicaciones, trataron el tema desde la perspectiva del excesivo centralismo porteño, subrayando diversos problemas como el de las tarifas, ${ }^{21}$ los accesos, el trazado de líneas férreas (Vilamajó, 1936), el dragado y canalización para buques de alto calado que requerían de políticas públicas para su resolución (Editorial. El Canal, junio de 1937, p. 1). En particular, Vilamajó introdujo el tema de la artificialidad del centralismo al considerar que la demora en la construcción del Canal Mitre -necesaria para el ingreso de buques de gran calado- no residía en motivos de orden técnico ni financiero, sino "artificiales", en el peligro que significaría para Buenos Aires perder parte del tráfico marítimo (Algunos comentarios, junio, 1937, pp. 2-6). Esta idea de la artificialidad de la centralización estaba presente también en los autores de Argentina en la post guerra, para quienes la descentralización del puerto de Buenos Aires, la adopción de medidas de desarrollo para el resto y la creación de zonas francas sólo era posible a través de las políticas estatales.

\section{EL PROBLEMA DEL CRÉDITO INDUSTRIAL}

Otro de los temas que ilustra la convergencia entre profesionales y empresarios es el crédito industrial. El perfil comercial de la ciudad y su necesidad de hacer frente a las coyunturas difíciles explicaron la importante

${ }^{20}$ Gregorio Meira se graduó de doctor en Ciencias Económicas en la Universidad Nacional del Litoral, publicó trabajos sobre el tema portuario y sobre industria (Meira, 1942, 1945). Ambos trabajos fueron publicados en la Revista de la Facultad de Ciencias Económicas, Comerciales y Politicas y luego en la Revista. Fue docente en dicha facultad y más tarde integrante de la comisión liquidadora del Instituto Argentino para la Promoción del Intercambio, director de Yacimientos Petrolíferos Fiscales entre 1956 y 1958 y secretario de Estado de Energía y Combustibles desde 1958 (Abad de Santillán, 1967). Meira ostentaba una posición diferente a la aquí analizada, pues aseguraba no aceptar el intervencionismo estatal "desmedido", ni la industrialización "a cualquier precio", ni propiciar la autarquía "u otras antinaturales medidas similares". No obstante, era preciso "independizar el mercado nacional en tanto y en cuanto lo permitan las reales posibilidades de la Nación”. Meira (1942).

21 "Los derechos portuarios deben ser equivalentes a las retribuciones de los respectivos servicios prestados, pues lo contrario equivale a establecer impuestos indirectos a la circulación de mercaderías, obstaculizando por lo tanto el desenvolvimiento económico de nuestra ciudad" (Adhesión a las gestiones, agosto, 1942, pp. 18-20). 
proliferación de instituciones de crédito públicas y privadas y de compañías aseguradoras (Fernández y Armida, 2000), a lo cual se sumaba la necesidad específica de contar con préstamos a largo plazo para financiar las actividades industriales. De modo que desde mediados de la década de 1930 estudios y publicaciones generadas desde la Facultad de Ciencias Económicas en el marco de la cátedra de Bancos, el seminario o las tesis, abordaron el problema del crédito en general y del crédito industrial en particular. ${ }^{22}$

Entre las organizaciones industriales el problema del crédito se instaló con particular fuerza durante los debates en torno al Plan Pinedo. Tanto la porteña Unión Industrial Argentina como la Federación Gremial aprobaron las ideas contenidas en el plan. Los industriales rosarinos argumentaron que en el interior los síntomas de la depresión económica eran mayores, por lo cual pedían créditos y participación en el trazado de las políticas de financiamiento (Editorial: El programa, noviembre, 1940; Nota al presidente, noviembre, 1940).

Reclamaban la creación de un banco de crédito industrial o una sección especial en el Banco de la Nación que implementase préstamos a reducido interés y plazos de diez a quince años, con garantía de prenda sin desplazamiento de maquinaria, instalaciones y mercaderías. Comenzaron por estos años a esgrimir un argumento que se generalizaría, el reclamo en nombre de los pequeños y medianos industriales, base cada vez más nutrida de la organización: "es común observar en el país el caso de un obrero que luego se convierte en patrón, empresario y por último propietario de una gran industria" (Editorial: Necesidad de crédito, junio, 1941, p. 1) que dependía especialmente de la disponibilidad de créditos. En general estos empresarios contaban con letras que debían descontarse en tres o seis meses y no resolvían el problema, "de ahí que se deba apresurar la producción y venta del artículo - a veces en desmedro de la calidad- para hacer frente al rápido vencimiento" (p. 1) y por supuesto carecía de las posibilidades de las sociedades anónimas, de emisión de obligaciones o acciones.

\footnotetext{
${ }^{22}$ Isaac Blustein realizó su tesis para optar por el título de doctor en Ciencias Económicas sobre el tema del crédito industrial (Blustein, 1939) y publicó también textos que abordaban temas afines. La bibliografía de la tesis revela publicaciones sobre el tema bancario de Francisco Lecchini y Natalio Muratti, maestro de Blustein. Francisco Lecchini era doctor en Ciencias Económicas, egresado de la Universidad Nacional del Litoral; entre 1958 y 1959 fue intendente de la ciudad de Rosario. Muratti se había recibido de doctor en Ciencias Económicas con una tesis sobre el tema de servicios públicos (Muratti, 1928). Publicó sobre banca, seguros y cambios; fue docente, consejero y director de la Revista de la Facultad de Ciencias Económicas, Comerciales y Políticas hasta 1947, cuando tras la intervención de la Universidad Nacional del Litoral por parte del peronismo pasó a dirigir el Instituto de Investigaciones Económicas de Federación Gremial. Se desempeñó también como síndico de la ex empresa Mixta de Transportes de Rosario y como miembro de la Comisión investigadora de la ex Compañía de Aguas Corrientes (Menecier, 1951; Rosario biográfico, 1955).
} 
Desde entonces las demandas de crédito industrial, es decir, a plazos más largos y con bajas tasas, aparecieron de manera sostenida entre los industriales locales. Francisco Scarabino, diputado nacional rosarino por los radicales antipersonalistas de la Unión Cívica Radical de la Provincia de Santa Fe, fue quien presentó el proyecto de creación de una sección de crédito industrial en el Banco de la Nación Argentina (Federación Gremial del Comercio y la Industria, Memoria, 1942; Editorial: Necesidad de crédito, junio, 1941; Proyecto de ley, junio, 1941; Notas parlamentarias, julio, 1941). Los proyectos presentados en temas como fomento industrial, rebajas de fletes ferroviarios para traslado de productos de la minería, reformas de las leyes de trabajo para permitir la implantación del aprendizaje a menores de 18 años, modificación de los derechos aduaneros y prioridad en las licitaciones de las reparticiones públicas y empresas concesionarias de los servicios públicos a la industria nacional, fueron difundidos en el mundo empresarial a través de sus publicaciones (Federación Gremial del Comercio y la Industria, 1942; Murmis y Portantiero, 1971, p. 52). ${ }^{23}$

En ese nuevo contexto los autores de Argentina en la post guerra retomaron y continuaron las investigaciones realizadas en el marco académico y analizaron los limitados datos que emergían de las memorias de instituciones de crédito, a partir de lo que interpretaban como un proceso de concentración bancaria. Con la recopilación de los datos disponibles de capitales y reservas, plantearon que el Banco de la Nación prestaba 85.9 pesos si se trataba de un solicitante de Capital Federal y 57.1 si era del interior; los demás bancos que operaban en el país lo hacían en 73.3 y 59.3\%, respectivamente; aquellos bancos que operaban sólo en Capital Federal prestaban 69.7 pesos y los que funcionaban sólo en el interior, 84.2 pesos. Señalaban: "Queda así patentizado un hecho desconcertante: la economía del interior del país nutre con sus depósitos, en buena parte, la de la Capital Federal, cuando sería de esperar el fenómeno inverso, o sea que ella, como centro económico del país, volcara parte de sus recursos propios en el interior, que tanto los necesita para desarrollar las posibilidades económicas que yacen dormidas por falta de crédito habilitador" (Cristiá et al., 1946, p. 451). Esto significaría otorgar préstamos al interior por 467300000 pesos, 29.6\% más, afirmaban.

Estos datos representaban argumentos que respaldaban las peticiones empresariales de fomento del crédito industrial, creación de instituciones en el interior y aumento de atribuciones a sus funcionarios. Por cierto, la creación del Banco de Crédito Industrial Argentino en 1944 y de la su-

\footnotetext{
${ }^{23}$ Además de rosarino, Scarabino era abogado y empresario de diversas actividades. Pertenecía a las firmas Muebles Scarabino Hnos. Ltda., Inmobiliaria Scarabino Hnos., Cía. Argentina de Carbones (para la provisión de fundiciones) y Diario La Acción (Diccionario biográfico, 1945). Comenzó su carrera política en el seno del Partido Demócrata Progresista (Abad de Santillán, 1967).
} 
cursal Rosario un año después, fueron apoyadas con beneplácito por los industriales locales, quienes las consideraron un "esfuerzo orgánico digno de todo elogio", aunque resultado de la lucha de las organizaciones industriales (Federación Gremial del Comercio y la Industria, 1944). Exaltaban sus propósitos de dotar de créditos a la industria del conjunto del país y a la pequeña y mediana en particular, mediante créditos a largo plazo, en línea con lo sostenido por otras organizaciones empresariales, en particular, la Unión Industrial Argentina. Sin embargo, a partir del análisis de la primera memoria del Banco, advertían el predominio de los préstamos a grandes industrias, pues casi $80 \%$ de las sumas prestadas correspondían a préstamos superiores a los 100000 pesos.

Las cifras expuestas mostraban además la absorción de los créditos en Buenos Aires, que consideraban agravante de la concentración, lo cual explicaban por la participación en el Directorio del Banco de industriales designados por la porteña Unión Industrial Argentina: "El Interior... bien, gracias" afirmaban (Cristá et al., 1946, p. 450). La relevancia que adoptaban las pequeñas industrias en el interior era superlativa: "No olvidemos que en la Capital Federal una fábrica o industria que tiene un capital de un cuarto de millón, puede tener poca importancia para la economía en general, en el Interior del país, esa fábrica o industria puede dar vida a un barrio o a más de una pequeña ciudad. A ello debe ser dirigida la acción del Banco, así como a la pequeña industria que actúa en el interior de la república”, p. 451.

Las posturas de estos intelectuales eran reproducidas en las páginas de la Revista (Cristiá, 1945b) en tanto reflejaban criterios convergentes de evaluación y diagnóstico: "el Banco no intensifica su acción hacia la pequeña y mediana industria, ni distribuye sus créditos por igual entre aquellas radicadas en el interior y en la Capital" (pp. 17-19). De los datos analizados, resaltaban la disonancia entre la cantidad de operaciones y los montos, pues si bien las operaciones menores de 20000 pesos representaban $63.6 \%$ del total, el monto correspondía a $6.1 \%$ de las sumas totales prestadas. Los préstamos superiores a 100000 pesos representaban 14.8\% de las operaciones, pero $79.9 \%$ de las sumas prestadas. Esta situación era contrastada con las manifestaciones públicas del Directorio del Banco en su primera memoria, que subrayaba la "amplia acción de ayuda a la pequeña industria". Por último, volvían sobre el argumento de la concentración industrial, al exponer que si bien $55.5 \%$ de las fábricas se concentraba en Capital Federal, hacia allí se había dirigido 70\% de los créditos otorgados, mientras al interior, donde se encontraba $44.55 \%$ de las industrias, se había destinado 30\% de los créditos (Cristiá, 1945b). ${ }^{24}$

${ }^{24}$ Es preciso aclarar que la sucursal rosarina del Banco de Crédito Industrial Argentino se habilitó ese mismo mes. Las críticas en idéntico sentido se van a mantener durante los años posteriores 
En síntesis, la producción universitaria de la década de 1930 en temas financieros y bancarios fue continuada en la década posterior, cuando los empresarios comenzaron a reclamar sistemática y enfáticamente políticas de crédito industrial que atendieran las exigencias de los grupos empresarios del interior. A partir de estos años, comenzaron a cuestionar tenazmente la política crediticia del Banco de Crédito Industrial, formulando de manera temprana una serie de críticas ante una política que no se revertiría en años posteriores.

\section{CONCLUSIONES}

Hacia mediados de la década de 1940, el proceso de afianzamiento de la industria rosarina se había acentuado, combinando una destacada presencia de capitales extranjeros con otra muy significativa participación de capitales locales, tanto de gran porte como de pequeñas y medianas proporciones. Estos últimos sectores industriales, de capitales nacionales, encontraron un canal de representación en la Federación Gremial del Comercio y la Industria de Rosario. A través de sus principales medios de expresión, difundieron un conjunto de ideas favorables a la industrialización -el incremento de la participación estatal en sus distintos niveles, la importancia de los industriales nacionales en dicho proceso, la necesidad de propiciar la descentralización económica-, que concurrían en el proyecto de convertir a Rosario en una ciudad industrial.

A través del análisis de los debates en torno a dos problemas cruciales para la expansión industrial regional -la reactivación y administración del puerto local y la pugna por la ampliación del crédito industrial- hemos mostrado la diversidad de actores participantes y la relevancia otorgada a los temas de la descentralización industrial. En efecto, en esas controversias se acentuaron los planteos federalistas, que se convirtieron en la lente a partir de la cual empresarios, intelectuales y profesionales interpretaron los procesos económicos nacionales. El federalismo representó un hilo conductor en los discursos de empresarios, profesionales, académicos e intelectuales durante estos años. Este sesgo otorgó un ingrediente peculiar y distintivo a las ideas económicas que circularon en los ámbitos locales y que se superpuso a ejes de debate transitados por industriales e intelectuales porteños.

Si el tema del puerto amalgamaba a diversas fracciones empresariales, funcionarios, intelectuales y profesionales, el más novedoso asunto de los

(Simonassi, 2012). Para una discusión sobre los alcances y límites de la política crediticia del peronismo mediante el Banco de Crédito Industrial Argentino, véanse Girbal (2003) y Rougier (2001). 
pedidos de créditos para la industria adelantaba un rasgo novedoso que se acentuaría en las décadas posteriores: la progresiva identificación de las demandas de la industria local con el pequeño y mediano empresariado.

Hemos demostrado a lo largo del artículo la presencia de tramas sociales amplias que excedían a los grupos empresariales pero que los integraban, ya visibles en la década de 1930 y fortalecidas durante los años de la guerra, nutrida de intelectuales y profesionales egresados de la universidad local. Se trataba de una red heterogénea, tanto en términos generacionales como sociales e identitarios.

En cuanto a los profesionales-intelectuales, estos eran portadores de un saber acumulado en el ámbito universitario, sitio que puede ser considerado relativamente autónomo de las clases. No obstante, en el caso de los economistas, su propia actividad privada como asesores, síndicos o contadores, los acercaba a los empresarios, generando tramas que culminaban en la elaboración de escritos, muchos de los cuales se publicaban simultáneamente en la Revista de la Facultad de Ciencias Económicas y en la Revista. Es posible pensar a los economistas e ingenieros como "intelectuales orgánicos", en tanto expertos que ponían los conocimientos aprendidos e impartidos en las propias facultades donde desempeñaban sus tareas docentes y de gestión, al servicio del empresariado local. Se crearon de ese modo tramas de vínculos que recorrían el mundo académico y las corporaciones empresariales. En cuanto a los líderes empresariales que se destacaron en los debates, es posible pensar en la conformación de una elite empresarial que ostentó una importante capacidad de organización, al tiempo que exhibieron una relevante capacidad dirigente y técnica en el ambiente local y regional de negocios.

En este sentido, Argentina en la post guerra -y el conjunto de los emprendimientos editoriales asociados a ese grupo- puede pensarse como culminación de un proceso previo de preparación y formación intelectual que se articuló más decididamente en los años finales de la guerra, representando un capital intelectual que fortaleció las demandas empresariales. Puede considerarse también como una de las experiencias de corte regional más coherentes y articuladas, en torno a la exaltación del desarrollo industrial nacional y regional, la denuncia del centralismo porteño y el estudio sistemático de sus principales problemas. Por fuera de esta red, hemos mostrado que otros académicos fueron leídos y citados en temas específicos como los aquí trabajados.

Pero ese "paraguas" que pudo configurar el federalismo en tanto práctica y discurso no borró -ni se propuso- las cesuras de clase. Si las agendas se formularon desde la común pertenencia a Rosario y su región, se limitó ostensiblemente a la Rosario empresarial, intelectual y profesional, excluyendo a otros sectores sociales. 
Es posible conjeturar que las propuestas de descentralización económica y la particular perspectiva desde la cual pensaron y actuaron los agentes económicos locales -el federalismo-, chocaron con los proyectos nacionales -centralizadores- del peronismo y al menos generaron una relación tensa y conflictiva con el régimen. Durante el peronismo, los industriales locales aprovecharon las oportunidades abiertas por las políticas industriales, pero la convergencia ideológica de los mismos con el populismo peronista encontró en el federalismo una barrera, un límite difícil de franquear. Estas conjeturas se refuerzan ante otra de las características distintivas del caso rosarino, la fuerte matriz local de los debates, con escasos -mas no inexistentes- vínculos orgánicos con tramas empresariales e intelectuales de Buenos Aires.

En este sentido, algunos de los participantes en estas controversias confluyeron en el peronismo, destacándose el caso de Enrique Vilamajó, quien se desempeñó como ministro de Hacienda durante la gubernatura del ingeniero José Caesar en la provincia de Santa Fe. Las posturas en torno al desarrollo industrial por ellos sostenidas convergieron con los aspectos medulares de las políticas estatales del peronismo. No obstante, otros se ubicaron en las filas del antiperonismo, ocupando distintos cargos públicos o en las universidades tras el golpe de 1955.

\section{LISTA DE REFERENCIAS}

Abad de Santillán, D. (1967). Gran enciclopedia de la Provincia de Santa Fe. Buenos Aires: Ediar.

Adhesión a las gestiones realizadas por el poder ejecutivo de la provincia sobre la creación de una comisión local (agosto, 1942). Revista de la Federación Gremial del Comercio y la Industria. 179, 21.

Algunos comentarios acerca del Canal Mitre (junio, 1937). Revista de la Federación Gremial del Comercio y la Industria. 117, 2-6.

Argentina económica. Próxima publicación de gran interés (octubre, 1943). Revista de la Federación Gremial del Comercio y la Industria. 193, 36.

Astesano, E. (1950). Teoría y práctica sobre zona económica argentina. Rosario: Editorial Rosario.

BaCOLla, N. (2010). Estado, política y economía en la Argentina de entreguerras. Itinerarios y debates en la Revista de Economía Argentina. En M. I. TATO y M. CASTRO (comps.), Del centenario al peronismo. Dimensiones de la vida política argentina. Buenos Aires: Imago Mundi.

Badaloni, L. y Simonassi, S. (2008). Asociacionismo empresario y conflictividad social en la Rosario de entreguerras. En S. Fernández y O. Videla (comps.), Ciu- 
dad oblicua. Aproximaciones a temas e intérpretes de la entreguerra rosarina. Rosario: La Quinta Pata y Camino Ediciones.

BELINI, C. (2010). La industria como problema y como solución. Ideas, debates y propuestas durante la entreguerras, 1918-1943. En M. I. TATO y M. CASTRO (comps.), Del centenario al peronismo. Dimensiones de la vida política argentina. Buenos Aires: Imago Mundi.

BELINI, C. (2014). Convenciendo al capital. Peronismo, burocracia, empresarios y política industrial, 1943-1955. Buenos Aires: Imago Mundi.

Blustein, I. (1939). Contribuciones a la solución del crédito industrial en la República Argentina (Tesis doctoral). Universidad Nacional del Litoral, Argentina.

Caravaca, J. (2011). ¿Liberalismo o intervencionismo? Debates sobre el rol del Estado en la economía argentina, 1870-1935. Buenos Aires: Sudamericana.

Caravaca, J. y Plotkin, M. (octubre-diciembre, 2007). Crisis, ciencias sociales y elites estatales: la constitución del campo de los economistas estatales en la Argentina, 1910-1935. Desarrollo Económico, 47(187), 401-428.

CRistiá, P. J. (dir.) (1944a). Argentina económica e industrial. Rosario: Editorial Rosario.

CRistiÁ, P. J. (noviembre, 1944b). La industria y la enseñanza técnica. Revista de la Federación Gremial del Comercio y la Industria, 206, 17-27.

CRISTIÁ, P. J. (1944c). La industria y la enseñanza técnica. Rosario: Federación Gremial del Comercio y la Industria de Rosario (con la colaboración estadigráfica de Saul Montes).

CristiÁ, P. J. (1945a). Aspectos del problema eléctrico. Informe contrato de la Sociedad de Electricidad de Rosario: Empresa Municipal Mixta de Transporte de Rosario. La SER y la SOFInA. Rosario: Editorial Rosario.

CristiÁ, P. J. (septiembre, 1945b). Acción del Banco de Crédito Industrial. Revista de la Federación Gremial del Comercio y la Industria, 216, 17-19.

Cristiá, P. J., Díaz Molano, E., Gorbán, S., Lazarte, J., López-Mayer, A. y OtTaDO, V. (1946). Argentina en la post guerra. Rosario: Editorial Rosario.

Cristiá, P. J. y OtTAdo, V. (1946). Planificación ferroviaria sudamericana. Rosario: Editorial Rosario.

Daumas, E. (julio, 1930). El problema de la yerba mate. Revista de Economía Argentina, 25(145), pp. 15-66.

Daumas, E. (septiembre, 1940). Discurso del Sr. Ernesto Daumas. Revista de la Federación Gremial del Comercio y la Industria, 156, 4-8.

Daumas, E. (septiembre, 1941). Discurso del Sr. Ernesto Daumas, pronunciado el día 2 de septiembre en ocasión del día de la industria argentina. Revista de la Federación Gremial del Comercio y la Industria, 168, 7-12.

Diccionario biográfico de hombres de negocios, biografías contemporáneas (1945). Buenos Aires: Veritas/F. Antonio Hirsuto S. A. Editora y de Informaciones Comerciales.

Editorial: El Canal Mitre (junio, 1937). Revista de la Federación Gremial del Comercio y la Industria 117, 1. 
Editorial: El programa económico del poder ejecutivo. Revista de la Federación Gremial del Comercio y la Industria (noviembre, 1940). 158, 1.

Editorial: Necesidad de crédito industrial (junio, 1941). Revista de la Federación Gremial del Comercio y la Industria. 165, 1.

Federación Gremial del Comercio y la Industria de Rosario (1942). Memoria. (pp. 1-13) Rosario: Federación Gremial.

Federación Gremial del Comercio y la Industria de Rosario (1944). Memoria XXV Ejercicio. (pp. 1-16) Rosario: Federación Gremial.

FERnÁNDEZ, S. (2009). Crecimiento urbano y desarrollo local. Empresas y municipio en el negocio de la energía eléctrica en Argentina (1888-1947): el caso de la ciudad de Rosario. Boletín Americanista, 59.

FERnÁndez, S. y ARMidA, M. (2000). Una ciudad en transición y crisis (1930-1943). En A. Pla (coord.). Rosario en la historia (de 1930 a nuestros días) (t. 1). Rosario: Universidad Nacional de Rosario Editora.

Gerchunoff, P. y LlaCh, L. (2007). El ciclo de la ilusión y el desencanto. Un siglo de politicas económicas argentinas. Buenos Aires: Emecé.

Gilbert, J., Rougier, M. y Tenewicki, M. (2000). Debates en torno a la propuesta económica de Raúl Prebisch (1955-1956). XVII Jornadas de Historia Económica. Tucumán, Argentina.

Girbal, N. (2003). Mitos, paradojas y realidades en la Argentina peronista (1946-1955). Buenos Aires: Universidad Nacional de Quilmes.

GonzÁlez-Bollo, H. (2012). La teodicea estadística de Alejandro E. Bunge (1880-1943). Buenos Aires: Imago Mundi/Fundación Universidad Católica Argentina.

Gorbán, S. (1947). Planificación industrial. Rosario: Editorial Rosario.

Gorbán, S. (1950). Integración económica de América Latina (Tesis doctoral). Universidad Nacional del Litoral, Argentina.

Gorbán, S. (1951). Integración económica de América Latina. Rosario: Editorial Rosario.

Kofman, M., Lanciotti, N. y PÉrez, N. (2012). La industria santafesina desde la expansión agraria a la diversificación productiva, 1887-1964. En C. FRID y N. LANCIOTTI (coords.). De la expansión agraria al desarrollo industrial: la economía de Santa Fe entre 1850 y 1970. Rosario: Prohistoria Ediciones.

La futura administración del puerto de Rosario. Formula declaraciones el Sr. Ernesto Daumas (agosto, 1942). Revista de la Federación Gremial del Comercio y la Industria. Eentrevista realizada a Ernesto Daumas. 179, 18-20.

LÁZZARO, S. (1992). Estado, capital extranjero y sistema portuario argentino (1880-1914) (t. 1). Buenos Aires: Centro Editor de América Latina.

LeCChini, F. (septiembre, 1942). Sobre el puerto Rosario. Revista de la Federación Gremial del Comercio y la Industria, 180.

Llach, J. J. (enero-marzo, 1984). El Plan Pinedo de 1940, su significado histórico y los orígenes de la economía política del peronismo. Desarrollo Económico, 92. 
LLACH, J. J. (1985). La argentina que no fue. Tomo I. Las fragilidades de la Argentina agroexportadora (1918-1930). Buenos Aires: Ediciones del Instituto de Desarrollo Económico y Social.

LOBATO, M. (segundo semestre, 1998). La ingeniería: industria y organización del trabajo en la Argentina de entreguerra. Estudios del Trabajo, 16.

Lовато, M. (verano, 2003). Organización, racionalidad y eficiencia en la organización del trabajo en la Argentina. El sueño de la americanización y su difusión en la literatura y en la prensa. Sociología del Trabajo, nueva época, 49.

LÓPEZ-MaYer, A. (1946). Transportes en la Argentina. Rosario: Editorial Rosario.

Love, J. (abril-junio, 1996). Las fuentes del estructuralismo latinoamericano. Desarrollo Económico, 36(141), 391-401.

LuCChini, C. (1990). Apoyo empresarial en los orígenes del peronismo. Buenos Aires: Centro Editor de América Latina.

Magariños, M. (1991). Diálogos con Raúl Prebisch. México: Fondo de Cultura Económica/Banco Nacional de Comercio Exterior.

MeIRA, G. (1942). El puerto de Rosario, su pasado, su presente, su porvenir. Rosario: Imprenta de la Universidad Nacional del Litoral.

MeIrA, G. (1945). Reflexiones que sugiere la actual industrialización del país. Bases para un plan industrial. Rosario: Imprenta de la Universidad Nacional del Litoral.

Memoria de la Bolsa de Comercio de Rosario, años 1940-1942. Rosario, Argentina: Biblioteca de la Bolsa de Comercio de Rosario.

Menecier, E. (octubre, 1951). Palabras de presentación. Revista de la Federación Gremial del Comercio y la Industria.

Muratti, N. (1928). Municipalización de los servicios públicos. Estudio económico, financiero, político y social (Tesis doctoral). Universidad Nacional del Litoral, Argentina.

Murmis, M. y Portantiero, J. C. (1971). Crecimiento industrial y alianza de clases en la Argentina, 1930-1940. Estudios sobre los orígenes del peronismo. T. 1. Buenos Aires: Siglo XXI.

Neiburg, F. y Plotkin, M. (2004). Los economistas. El Instituto Torcuato Di Tella y las nuevas elites estatales en los años sesenta. Intelectuales y expertos. La constitución del conocimiento social en la Argentina. Buenos Aires: Paidós.

Nota al presidente del Senado solicitando representación en el organismo de financiación (noviembre, 1940). Revista de la Federación Gremial del Comercio y la Industria.158, 5.

Notas parlamentarias. Los proyectos del diputado Dr. Francisco Scarabino sobre fomento de la industria nacional (julio, 1941). Revista de la Federación Gremial del Comercio y la Industria. 166, 20-28.

PANTAleón, J. (2004). El surgimiento de la nueva economía argentina: el caso Bunge. En F. NeIBURG y M. PlotKin, Intelectuales y expertos. La constitución del conocimiento social en la Argentina. Buenos Aires: Paidós. 
Pereyra, H. (1995). Pinedo y el Plan económico de 1940. En W. Ansaldi, A. PuCCiARELLI y J. VILLARUEL, Representaciones inconclusas. Las clases, los actores y los discursos de la memoria, 1912-1946. Buenos Aires: Biblos.

Pollock, D., Kerner, D. y Love, J. (diciembre, 2001). Entrevista inédita a Prebisch: logros y deficiencias de la CEPAL. Revista de la CEPAL, 75.

Proyecto de ley sobre crédito industrial (junio, 1941). Revista de la Federación Gremial del Comercio y la Industria. 165, 25-32.

Quién es quién en Argentina. Biografías contemporáneas. (1955). Buenos Aires: Kraft Ltda.

Regalsky, A. y Jáuregui, A. (2003). Americanización, proyecto económico y las ideas de Alejandro Bunge en los años 20. En M. I. BArbero y A. Regalsky, Americanización. Estados Unidos y América Latina en el siglo XX. Buenos Aires: Editorial de la Universidad Nacional de Tres de Febrero.

Revista de la Federación Gremial del Comercio y la Industria (septiembre, 1943), 192, 50.

Rosario biográfico (1955). Rosario: Editora Tradiciones Argentinas.

Rougier, M. (abril, 2001). La política crediticia del Banco Industrial durante el primer peronismo, 1944-1955 (Documento de trabajo núm. 5). Argentina: Centro de Estudios Económicos de la Empresa y el Desarrollo, Facultad de Ciencias Económicas de la Universidad de Buenos Aires.

Rougier, M. y Odisio, J. (2014a). Post bellum. La Revista de Economía Argentina y los inicios del "industrialismo"(Documento de trabajo núm. 1, perspectivas sobre la industria.). Argentina: Área de Estudios Sobre la Industria Argentina y Latinoamericana.

Rougier, M. y Odisio, J. (2014b). Industrialismo mejorado: los argumentos económicos sobre la industrialización argentina hacia finales de los años treinta. XXIV Jornadas de Historia Económica Argentina. Rosario, Argentina, 2014.

Simonassi, S. (2006). Perfil industrial y dinámica social en la provincia de Santa Fe (1943-1976). En D. DE BARriera (comp.), G. Águila (dir.), Nueva historia de Santa Fe: De los cordones industriales al eje de integración Mercosur (1940-2005) (t. 11). Rosario: La Capital \& Prohistoria Ediciones.

SimOnASSI, S. (2011). Educar el cerebro o pensar con las manos: los industriales rosarinos y la formación técnica para el trabajo en los albores del peronismo. En D. Dicósimo y S. SimOnassi (comps.), Trabajadores y empresarios en la Argentina del siglo $X X$. Indagaciones desde la historia social. Rosario: Prohistoria Ediciones.

SimONASSI, S. (2012). Las organizaciones empresarias de la industria en Rosario 1930-1962 (Tesis de doctorado). Universidad Nacional de Rosario, Argentina.

SimONASSI, S. (2014). Prácticas asociativas e identidades: el empresariado industrial metalúrgico rosarino, la conflictividad laboral y la organización obrera en la etapa formativa del peronismo. En M. C. Bravo y S. Fernández, Formando el espacio público. Asociacionismo y política. Siglos XIX y XX. San Miguel de Tucumán: Universidad Nacional de Tucumán.

Vilamajó, E. (mayo, 1933). Comentarios sobre el proteccionismo. Revista de la Federación Gremial del Comercio y la Industria, 67, 9-10. 
Vilamajó, E. (agosto, 1936). Comentarios sobre el futuro de Rosario. Revista de la Federación Gremial del Comercio y la Industria, 107, 18-23.

VILAmajó, E. (mayo, 1938). Rosario y las industrias. Revista de la Federación Gremial del Comercio y la Industria, 128, 19.

Vilamajó, E. (septiembre, 1939). Comentario sobre la industria rosarina. Revista de la Federación Gremial del Comercio y la Industria, 144, 11-12.

Visitó nuestra ciudad el ministro de Obras Públicas de la nación y la Comisión Asesora del Puerto Rosario (julio, 1942). Revista de la Federación Gremial del Comercio y la Industria. 178.

\section{HEMEROGRAFÍA}

La Capital, Rosario, Argentina, años 1942 y 1945.

La Tribuna, Rosario, Argentina, años 1942 y 1945. 